ARTICLE

\title{
Transnational law as a framework for law clinics
}

\author{
Sital Kalantry ${ }^{1} \cdot$ Rachael Hancock ${ }^{2}$
}

Accepted: 2 December 2020 / Published online: 20 February 2021

(c) O.P. Jindal Global University (JGU) 2021, corrected publication 2021

\begin{abstract}
As the law becomes increasingly globalised and online education is increasingly emphasised, clinical legal education presents new opportunities for transnational collaboration. With more law schools introducing global clinical experiences into their curriculum, clinicians, students, clients, and practitioners are facing a host of new questions, challenges, and obstacles. These challenges are practical, logistical, ethical, and cultural. As research has found, finding a means of addressing these issues in ways that advance social justice has proven difficult. Striking a balance between client service and student learning, navigating relationships between different learning institutions, and setting ambitious but attainable goals are important elements of any clinic, but become increasingly vital for the success of a transnational clinical programme. Despite these obstacles and foundational questions, we argue that transnational clinical education presents benefits to all parties involved. This article assesses the methods, strengths, weaknesses, and outcomes of a collaboration between Cornell Law School's Human Rights Clinic and National Law University (NLU), Delhi, that took place in 2017. This clinic focused on advocacy in favour of lifting bans on compensated surrogacy in both India and New York, culminating in two reports, an event at the United Nations, and testimony before the New York State Assembly. Twelve students from Cornell Law School and eight students from NLU, Delhi met weekly in a 'global classroom' equipped with video and chat functions to discuss the goals of the clinic, background readings, and their respective projects within the clinic. Eight students from Ithaca travelled to Delhi for eight days, conducting interviews and engaging in fact-finding with NLU, Delhi students. Together, students and clinicians from Cornell Law School and NLU, Delhi authored two reports, one focused on the U.S., and one focused on India, which were disseminated to each country's governments. Our reflections on this programme are meant to serve as a learning experience for other clinicians considering implementing a transnational clinical legal education opportunity.
\end{abstract}

Keywords Transnational law $\cdot$ Legal aid $\cdot$ Clinical programme $\cdot$ Law school . Curriculum

Sital Kalantry-Clinical Professor of Law. Rachael Hancock-Law Clerk.

Extended author information available on the last page of the article 


\section{Introduction}

When legal clinics were first established in law schools in the U.S., they looked very similar to 'legal aid cells' in Indian law schools. Those clinics in the U.S. were often self-guided by students, who received no credit, and provided legal aid only to the local community. Although in India that model still prevails, starting in the 1960s, U.S. clinical programmes transformed significantly. Law schools now offer a wide variety of clinics and they are embedded within the law school pedagogical structure.

In the early 1980s, a new type of clinic emerged called the international human rights clinic (IHR clinic). The name of the clinic suggests that they examine violations of primarily international human rights law. The following international documents form the core of international human rights: the Universal Declaration of Human Rights, ${ }^{1}$ the International Covenant on Civil and Political Rights, ${ }^{2}$ and the International Covenant on Economic, Social, and Cultural Rights. ${ }^{3}$ International human rights law also includes other human rights treaties as policies and norms. International treaties typically only hold state actors accountable since they are the only ones that are parties to them. Today, many IHR clinics have moved away from a model of exclusively focusing on states and using only international human rights law, yet they continue to define themselves as 'international human rights clinics'. Although IHR clinics have adopted new approaches to their work, there has not yet been a thoughtful discussion about what principles might better reflect the work that IHR clinics are doing and should be doing to promote justice globally. We argue that the body of literature known as 'transnational law' might offer a better framework for clinics known today as IHR clinics. Transnational law is a concept that includes laws that regulate actions of state and non-state actors or events beyond national borders. $^{4}$

We argue that transnational law is a useful framework for clinics that work globally for three reasons. First, transnational law includes within its ambit multiple substantive areas of law both at the international and at the domestic level. Second and relatedly, transnational law includes within its scope the actions of both public and private actors. This allows clinics that are working on global issues to examine the important role that private actors play in perpetuating inequality and injustice. Third, a clinic that uses the domestic laws of the countries in which it works is more likely to collaborate with other clinics based in those countries in which it is addressing injustice. We believe that these collaborations are an important way to work on global justice problems across borders. We provide an example of how the lens of transnational law aligned with the clinical collaboration between two academic institutions (Cornell Law School, Ithaca, and NLU, Delhi).

\footnotetext{
1 Universal Declaration of Human Rights, General Assembly Res. 217 A(III), 10 December 1948.

2 International Covenant on Civil and Political Rights, 999 UNTS 171, 16 December 1966.

3 International Covenant on Economic, Social, and Cultural Rights, 993 UNTS 3, 16 December 1966.

4 See Peer Zumbansen, 'Transnational Law' in Jan Smits (ed), Elgar Encyclopedia of Comparative Law (Edward Elgar Publishing 2006) 738.
} 
In Section 2, we discuss the evolution of clinics and clinical legal education (CLE) in American law schools. In Section 3, we focus on the history and current status of human rights clinics in American law schools and then explain how the transnational law framework could be beneficial to guide those clinics in Section 4. In Section 5, we give an example of a clinical collaboration that aligns with a transnational law framework.

\section{Evolution of law clinics in U.S. law schools}

Some authors trace the beginning of CLE in the U.S. to the 1930s, when legal realists such as Karl Llewelyn and Jerome Frank introduced a new theory of legal education. Llewelyn and Frank emphasised the need for students to engage in the 'constant interaction of theory and practice' rather than merely the 'science of law'. According to them, law schools should strive toward a 'values-driven legal curriculum that conceives of the law as an instrument for social justice'. 6

Even before legal realists imagined a more experiential legal curriculum, the precursors to the modern legal clinic had already emerged at U.S. law schools. The first legal aid programmes were formed in large metropolitan cities in the late 19th century. ${ }^{7}$ The programmes were 'local in inspiration and limited in aspiration', focusing almost entirely on issues of poverty law. ${ }^{8}$ While these programmes started the tradition of law student participation in pro bono work and poverty law, students who participated in these programmes did so voluntarily, informally, and without receiving credit or pay. ${ }^{9}$ At the time, little attention was paid to how law students could fill gaps in the availability of legal services. ${ }^{10}$

CLE experienced a second wave of enthusiasm and transformation in the 1960s and 1970s. Arthur Kinoy is credited with spearheading this movement by encouraging educators to 'tak[e] on major cases and situations involving the relationship of the process of the law to the fundamental problems of contemporary society'. ${ }^{11}$ Encouraged by the Warren Court's attitudes toward due process and equal protection, poverty law was again the focus of most clinics. ${ }^{12}$ CLE was further bolstered by the rise of the Law and Society Movement, which brought economists, sociologists, anthropologists, psychiatrists, doctors, and other professionals into conversation

\footnotetext{
5 Deena Hurwitz, 'Lawyering for Justice and the Inevitability of International Human Rights Clinics' (2003) 28 Yale Journal of International Law 505, 523. This 'science of law approach' is mostly closely associated with Christopher Columbus Langdell of Harvard. See Stephen Wizner, 'The Law School Clinic: Legal Education in the Interests of Justice' (2002) 70 Fordham Law Review 1929, 1931.

6 Hurwitz, 'Lawyering for Justice' (n 5) 523.

7 Louise G Trubek, 'U.S. Legal Education and Legal Services for the Indigent: A Historical and Personal Perspective' (1994) 5(2) Maryland Journal of Contemporary Legal Issues 381, 382.

8 Ibid.

9 Ibid.

10 Ibid.

11 Arthur Kinoy, 'The Present Crisis in Legal Education' (1969) 4 Rutgers Law Review 1, 7, cited in Hurwitz, 'Lawyering for Justice' (n 5) 523.

12 Harold Hongju Koh, ‘Transnational Legal Process' (1996) 75 Nebraska Law Review 181, 188.
} 
with law faculty. ${ }^{13}$ In this time period, the Ford Foundation increased its financial commitment to supporting legal aid programmes, civil rights litigation, and CLE, increasing the frequency and efficacy of legal clinics. ${ }^{14}$

In the 1970s, legal clinics shifted from relying on local, sporadic legal aid programmes run by pro bono attorneys to utilising full-time law school clinical instructors who supervised law students both in the field and in a classroom setting. ${ }^{15}$ Modern legal clinics typically satisfy the following criteria: $(a)$ they are created through a law school with the intent that the programme be linked to the academic institution; (b) law students learn experientially, by providing legal services to real clients; (c) students are supervised by an attorney admitted to practice, normally a member of the law school faculty; $(d)$ clients served by the clinic generally cannot afford to hire private counsel and generally come from disadvantaged, underserved, or marginal sectors of the community; $(e)$ case representation is preceded or accompanied by a pedagogical programme that prepares students in substantive doctrine, skills, ethics, and values of law practice; and $(f)$ student receive academic credit toward graduation. ${ }^{16}$

Next, we discuss the emergence of international human rights clinics within the clinical legal education and how they built upon the traditional model to create new types of clinical pedagogy.

\section{International human rights law clinics: the past and the present}

As the legal clinic became more organised and professional, the President Carter administration's emphasis on international human rights fostered law schools' and non-governmental organisations' interest in this specific area of law. ${ }^{17}$ This interest in human rights culminated in the creation of the country's first human rights clinic at SUNY Buffalo School of Law in $1979 .{ }^{18}$ Soon after, Yale Law School and American University Washington College of Law started human rights clinics. ${ }^{19}$ During this time period, clinics generally broadened their focus from solely a social justice mission to one that emphasised enhancing legal practice-oriented skills. ${ }^{20}$

\footnotetext{
13 Ibid. (contrasting the 'hard, conservative strand' of the Law and Economics Movement with the 'somewhat more liberal' Law and Society Movement).

14 Ford Foundation, 'A Legacy of Social Justice'. https://www.fordfoundation.org/about/about-ford/alegacy-of-social-justice/. Accessed 24 June 2020. See also Richard J Wilson, 'Training for Justice: The Global Reach of Clinical Legal Education' (2004) 22(3) Penn State International Law Review 421, 424427 (discussing sources of international funding instrumental in the founding and expansion of clinical education both inside and outside the U.S.).

15 Trubek, 'U.S. Legal Education and Legal Services for the Indigent' (n 7) 385.

16 Wilson, 'Training for Justice' (n 14) 422-423.

17 Hurwitz, 'Lawyering for Justice' (n 5) 524.

18 Ibid. 525. Buffalo's human rights clinic operated until 1986, when it was transformed into an asylum and immigration clinic.

19 Ibid.

20 Ibid. 524.
} 
Throughout the 1990s and into the 21st century, the number of human rights clinics ballooned. ${ }^{21}$ Peter Rosenblum identifies the waning of the Cold War as a contributing factor to law schools' willingness to incorporate human rights into the curriculum, ${ }^{22}$ sometimes through the addition of a human rights clinic.

Many scholars have written about the benefits of involving universities, law students, and clinics in human rights work. ${ }^{23}$ International human rights clinics, however, deviated from the traditional model of clinics in two ways. First, unlike direct services clinics, most projects of human rights clinics do not generally serve individual clients. ${ }^{24}$ Indeed, many IHR clinic projects involve working with non-profit organisations. Many clinics do not consider these organisations 'clients' in the traditional sense, instead calling them 'partners'. While a service relationship typically exists between a lawyer and a client, the relationship between an IHR clinic and its partners is seen to be more on an equal footing. In some cases, IHR clinics might not even have organisations they are collaborating with, but are simply working to advance human rights norms and principles. $^{25}$

Second, IHR clinics, unlike some other clinics, do not always engage in litigation. Such clinics undertake a wide variety of projects that involve fact-finding missions, drafting country or region-specific reports, lobbying, legislative advocacy, and creating judicial or other handbooks. When IHR clinics do engage in litigation, some human rights clinics use litigation as 'a means to an end and not an end in itself', choosing to focus on a broader advocacy strategy. ${ }^{26}$

There are also a number of similarities between IHR clinics and non-IHR clinics. First, often clinics engage with one body of law such as immigration law, landlord-tenant law, or labour law. Similarly, traditional human rights clinics focus on a distinct area of law-international human rights. In theory, in whatever project they work on, IHR clinics apply or promote international human rights law in some way. International human rights law itself is very broad. The core of human rights law that IHR clinics rely on comes from United Nations treaties, resolutions, and other norms. But 'human rights law' can also include treaties, resolutions, and other norms from regional bodies, such as the Organization of American States.

Second, IHR clinics teach students skills that are similar to those they learn in non-IHR clinics. By conducting human rights fieldwork, students learn the 'constituent elements of lawyering': question framing, listening, drafting, persuasion,

\footnotetext{
21 Jocelyn Getgen Kestenbaum, Esteban Hoyos-Ceballos, and Melissa C del Aguila Talvadkar, 'Catalysts for Change: A Proposed Framework for Human Rights Clinical Teaching and Advocacy' (2012) 18(2) Clinical Law Review 459, 464.

22 See Peter Rosenblum, 'Teaching Human Rights: Ambivalent Activism, Multiple Discourses, and Lingering Dilemmas' (2002) 15 Harvard Human Rights Journal 301, 302.

${ }^{23}$ For a description of human rights clinics' comparative advantage, see Arturo J Carrillo and Nicolás Espejo Yaksic, 'Re-imagining the Human Rights Law Clinic' (2011) 26 Maryland Journal of International Law 80, 84. For an argument that universities play a unique role in human rights, see Henry J Steiner, 'The University's Critical Role in the Human Rights Movement' (2002) 15 Harvard Human Rights Journal 317.

24 Hurwitz, 'Lawyering for Justice' (n 5) 533.

25 Ibid.

26 Kestenbaum et al., 'Catalysts for Change' (n 21) 466.
} 
fact-gathering, synthesising and marshalling information, investigation, problem solving, and advising, among other skills. ${ }^{27}$ In addition to the hands-on experiences human rights clinics offer, these clinics also provide a forum for reflection, innovation, and interdisciplinary work.

Since their founding in the early 1980s, international human rights clinics have expanded to a host of law schools and undertake a diverse set of projects. Although traditionally IHR clinics focused on applying international human rights law to hold state actors in foreign countries accountable for human rights violations, in today's world IHR clinics do much more than that: IHR clinics may apply domestic (either federal or state) law as well to cross-border, domestic, or foreign issues. For example, some clinics, like the University of Miami School of Law's Human Rights Clinic, have used both federal and state law to address the impact of anti-immigrant laws in the U.S. ${ }^{28}$ Berkeley Law's International Human Rights Clinic has also made extensive use of domestic and state law to pursue legal redress in the U.S. and Mexico for killings by U.S. border agents. ${ }^{29}$

In a few U.S. law schools, clinics that work across borders or apply international law no longer operate under the title 'international human rights clinic'. For example, at the University of Pennsylvania Law School, the clinic that works to advance equality and rights for communities around the world is called the 'Transnational Legal Clinic'. ${ }^{30}$ Similarly, one of Cornell's clinics is called the Gender Justice Clinic, which offers students the chance to 'engage in local, global and transnational efforts to advance gender justice'. ${ }^{31}$ At New York University, the Global Justice Clinic works 'to prevent, challenge, and redress rights violations related to global inequity' by working on cases and projects that involve domestic and cross-border human rights violations. ${ }^{32}$ At the University of Texas at Austin, the Transnational Worker Rights Clinic allows students to work as lead counsel representing transnational migrant workers in litigation, and helps to adapt U.S. law to better serve the global workforce. ${ }^{33}$ In the next section, we argue that transnational law rather than

\footnotetext{
27 Ibid. 467.

28 University of Miami School of Law, 'Human Rights Clinic: Project \& Cases'. https://www.law.miami .edu/academics/clinics/human-rights-clinic-projects. Accessed 24 June 2020.

29 Berkeley Law International Human Rights Law Clinic, Elusive Justice: Pursuing Legal Redress in the United States and Mexico for Killings by U.S. Border Agents (IHRLC Working Paper Series No. 3, August 2015) 37-48. https://www.law.berkeley.edu/wp-content/uploads/2015/09/Working-Paper-ElusiveJustice-LARGE-FINAL.pdf. Accessed 24 June 2020.

30 Penn Law, 'Learning from Every Client: Penn Law's Transnational Legal Clinic' (11 September 2017). https://www.law.upenn.edu/live/news/7337-learning-from-every-client-penn-laws-transnational. Accessed 24 June 2020.

31 Cornell Law School, Gender Justice Clinic. https://www.lawschool.cornell.edu/Clinical-Programs/ global-gender-justice/index.cfm. Accessed 24 June 2020.

32 Center for Human Rights \& Global Justice, Global Justice Clinic. https://chrgj.org/focus-areas/globa 1-justice-clinic/. Accessed 24 June 2020.

${ }^{33}$ University of Texas at Austin School of Law, 'Learn More about the Transnational Worker Rights Clinic'. https://law.utexas.edu/clinics/transnational-worker-rights/course-info/about/. Accessed 24 June 2020 .
} 
international human rights might provide a better organising principle for clinics that work on global injustice across borders.

\section{Transnational law: A framework for clinics addressing global injustice across borders}

It has been nearly 50 years after the first IHR clinic was formed. One of the authors (Sital Kalantry) has directed an IHR clinic for nearly 15 years. It is an ideal time to pause and take stock of where we are and where we might go. While some clinics in the U.S. that work globally use the words 'transnational' in their titles, authors have not identified a framework or set of principles that might guide the work of clinics that consider themselves 'transnational'. We argue that it is useful to take an in-depth look at the body of literature known as 'transnational law' for insight on a new framework for clinics that work global injustice issues. In 1956, Philip Jessup conceptualised the term 'transnational law', using it to refer to 'all law which regulates actions or events that transcend national frontiers. Both public and private international law are included, as are other rules which do not wholly fit into such standard categories. ${ }^{34}$

Harold Koh asserts that we might think of transnational law that is "neither purely domestic nor purely international, but rather, a hybrid of the two' ${ }^{35}$ Carrie MenkelMeadow describes transnational law as 'the study of legal phenomena, including lawmaking, rules, and legal institutions that affect or have the power to affect behaviors beyond a single border'. ${ }^{36}$ We can also conceive of transnational law as 'the interaction between domestic laws in the increasingly global web of connections among people, corporations, goods, services, and knowledge'. ${ }^{37}$

While the term transnational law can refer to a body of law, it can also refer to a methodology. ${ }^{38}$ Some scholars such as Peer Zumbansen have argued that transnational law should be used 'as a lens through which to perceive the argumentative parallels between the impasses, roadblocks and impossibilities of law that recur, both inside and outside the nation-state' ${ }^{39}$ For situations where people, practices,

\footnotetext{
34 Zumbansen, 'Transnational Law' (n 4) 738.

35 Harold Hongju Koh, 'Why Transnational Law Matters' (2006) 24 Penn State International Law Review 745, 745-746, describing types of transnational law: (a) law that is 'downloaded' from international law to domestic law; $(b)$ law that is 'uploaded then downloaded', in cases of laws that originate in domestic legal systems and then become a part of international law; and (c) law that is borrowed or 'horizontally transplanted' from one national system to another.

${ }^{36}$ Carrie Menkel-Meadow, 'Why and How to Study "Transnational" Law' (2011) 1 UC Irvine Law Review 97, 104.

37 Sital Kalantry, 'Transnational Legal Feminisms: Challenges and Opportunities' (2019) 52 Cornell International Law Journal 171, 172.

38 Peer Zumbansen, 'Defining the Space of Transnational Law: Legal Theory, Global Governance, and Legal Pluralism' (2012) 21 Transnational Law \& Contemporary Problems 305, 312: '[T]ransnational law constitutes a methodological shift in legal theory - an attempt to bridge the experience of legal pluralism in the nation-state with that of the emerging transnational space.'

39 Ibid.
} 
and knowledge move across borders regularly, fluidly, and quickly, transnational law orders a means to consider multiple contexts and design appropriate regulations for cross-border practices. ${ }^{40}$ As a methodology, transnational law emphasises both the international and the domestic or local, which in turn encourages clinics to examine the multiple contexts that give rise to a policy, law, practice, or rule. Using actors, norms, and processes as building blocks of a methodology, ${ }^{41}$ transnational law highlights the interactions between domestic laws and contexts in a global web of connections. $^{42}$

Transnational law gives a framework and cohesion that reflects the way in which IHR clinics have evolved, but also opens up new directions for clinics that aim to work across borders on rectifying injustices. First, transnational law implicates numerous areas of substantive laws, including (but not limited to) corporate law, domestic civil rights laws, and international criminal laws. Under the label of transnational legal clinic, there is more flexibility to engage with areas of law other than international human rights. Again, even though their clinic names include the label 'international human rights', many of the existing IHR clinics are not exclusively using international human rights law as a tool for accountability. For example, George Washington University Law School's IHR clinic partnered with the Southern Poverty Law Center to advance litigation on behalf of Central American guest workers in the U.S. This project involved using U.S. domestic employment law to advance the rights of immigrants. ${ }^{43}$ Similarly, the IHR clinic at Rutgers Law School has worked on election security issues within the U.S. through the lens of U.S. constitutional law. ${ }^{44}$

Cornell Law School's semester-long collaboration with Jindal Global Law School's Good Rural Governance and Citizen Participation Clinic (henceforth Citizen Participation Clinic) is another example of a clinic incorporating numerous areas of substantive law. Professor Ajay Pandey developed the Citizen Participation Clinic as an experiment using CLE as a bridge between the promises of international human rights and the lives of the majority of the Indian population. ${ }^{45}$ Because this clinic focuses on issues of food, education, health, social security, rural employment, and access to justice and legal aid, Pandey describes this clinic as serving as a model for involving clinicians and law schools in a 'socially relevant programme

\footnotetext{
${ }^{40}$ Sital Kalantry, Women's Human Rights and Migration: Sex-Selective Abortion Laws in the United States and India (University of Pennsylvania Press 2017) 40.

41 Zumbansen, 'Defining the Space of Transnational Law' (n 38) 308.

42 Kalantry, Women's Human Rights and Migration (n 40) 40. For a discussion of transnational legal feminism as a methodology, see Sital Kalantry, 'Transnational Legal Feminist Approach to Cross-Border Practices', in ibid.

43 George Washington University Law School, 'Human Rights Clinic Docket'. https://www.law.gwu.edu/ human-rights-clinic-docket. Accessed 26 June 2020.

44 Rutgers Law School, International Human Rights Clinic. https://law.rutgers.edu/international-human -rights-clinic. Accessed 28 June 2020.

45 Ajay Pandey, 'Experimenting with Clinical Legal Education to Address the Disconnect between the Larger Promise of Law and Its Grassroots Reality in India' (2011) 26 Maryland Journal of International Law $135,140$.
} 
for the benefit of the poor and illiterate rural masses. ${ }^{46}$ As part of this collaboration, Jindal students consulted with community members, advising them on potential avenues for redress, and assisting with filing complaints and petitions. ${ }^{47}$ Jindal students then shared their experiences with Cornell students over video conference. Cornell students contributed to the clinic's mission by conducting legal and factual research during their fieldwork around Sonepat in India. As one student remarked, ' $\mathrm{t}$ ] he cross-national aspect of this clinic made it a one-of-a-kind experience. The use of technology enabled us to have a single, integrated class despite having two sets of students and professors separated by over 7,000 miles. ${ }^{48}$

Second, transnational law includes within its ambit both private law and public law, which better allows clinics to engage with actors beyond just states. A traditional IHR clinic project involves critiquing state actions and holding governments accountable for human rights violations. However, non-state actors (such as corporations) are increasingly becoming more powerful than state actors. Typically, private law governs the behaviour of businesses. Though this is outside of the scope of how IHR clinics describe their mission (i.e., to use international human rights law to hold state actors accountable), some IHR clinics have already engaged in projects that critique the behaviour of businesses and attempt to hold them responsible. In doing so, they often refer to international private law as well as domestic law. For example, the International Human Rights Program at the University of Toronto's Faculty of Law used private law to influence the behaviour of a private actor: GoldCorp, a Canadian mining company. ${ }^{49}$ Following GoldCorp's announcement of new human rights and corporate social responsibility policies, the IHR clinic put together a report analysing, critiquing, and suggesting improvements to these policies in advance of the company's annual shareholder meeting. ${ }^{50}$ Similarly, at Santa Clara University, students in the IHR clinic partnered with Earth Rights International to draft legislation regarding corporate veil piercing, ${ }^{51}$ leading to California's

\footnotetext{
46 Ibid. 145.

47 Sital Kalantry, Elizabeth Brundige, and Priya S Gupta, 'Promoting Clinical Legal Education in India: A Case Study of the Citizen Participation Clinic' (2012) Cornell Law Faculty Publications, 6. https:// scholarship.law.cornell.edu/cgi/viewcontent.cgi?article=2538\&context=facpub. Accessed 30 November 2020.

48 Ibid. 7.

49 University of Toronto Faculty of Law, 'GoldCorp Human Rights and CSR Policies'. https://ihrp.law. utoronto.ca/page/working-group-and-clinic-reports/goldcorp-human-rights-and-csr-policies. Accessed 14 July 2020.

50 See Renu Mandhane, 'Actions Speak Louder Than Words: A Critical Analysis of GoldCorp's Human Rights and Corporate Social Responsibility' (11 May 2011). https://ihrp.law.utoronto.ca/sites/ihrp.law. utoronto.ca/files/documents/WorkingGroup_Clinic/IHRP\%20FINAL\%20Report\%20on\%20GoldCorp \%20Policies\%20May\%2016\%202011.pdf. Accessed 25 June 2020; GoldCorp updated its human rights policy in December of 2015 to 'reflect the changing social context' in which it operates. See 3BL Media, 'Goldcorp Updates Its Human Rights Policy' (10 December 2015). https://www.3blmedia.com/News/ Goldcorp-Updates-Its-Human-Rights-Policy. Accessed 25 June 2020.

51 Santa Clara University School of Law, 'Cases and Projects: Business and Human Rights'. https://law. scu.edu/ihrc/cases-and-projects/business-and-human-rights/. Accessed 25 June 2020.
} 
Assembly Bill 15. ${ }^{52}$ Penn Law's Transnational Legal Clinic has also engaged in projects that rely on input from private parties, local business, as well as international law for its work in Haiti. ${ }^{53}$

Third, a clinic that is working to address global injustice using many different substantive areas of law is more likely to invite collaborations with clinics in academic institutions in other countries. If a global clinic in the U.S. using transnational law as its guiding principles wants to address injustice in Indonesia, it will also want to examine how Indonesian law could be used to solve the problems. However, a law clinic supervised by a U.S. trained lawyer and consisting of U.S. law students would not have the expertise to navigate Indonesian law; instead, it should seek experts in Indonesia to work with. Thus, clinics that use a wider lens than international human rights are more likely to engage in cross-border clinical collaborations.

Cross-border clinical collaborations can be beneficial for many reasons. James Silk has noted that there are already 'projects where the clinics in the Global North and Global South work as equal partners' ${ }^{54}$ In response to Daniel Bonilla's essay describing a 'vertical relationship' of Global North domination in clinical collaboration, Silk argues that collaborators in the Global North and the Global South have more in common with each other than they do with the vulnerable populations whose human rights are at stake. ${ }^{55}$ Given the commonality between these collaborators, Silk argues that the value added by transnational legal clinical education is that it inspires a commitment to empathy and solidarity. Silk is thus optimistic that practitioners and clinicians can create equal, efficient, and important relationships between legal clinics in the Global North and the Global South.

Sarah Paoletti also highlights the benefits of transnational clinical collaborations. She argues that the value of clinical programmes is enhanced by incorporating crossborder peer-to-peer collaborations because they provide a space to engage with differing perspectives, serving both a clinic's pedagogical goals and providing legal services. ${ }^{56}$ Paoletti further argues that cross-border clinics offer better opportunities for critical reflection on the role of law and lawyering in human rights advocacy and interdisciplinary clinical work. Paoletti emphasises that the systematic development of these programmes is vital to avoiding some of the problems with collaborative transnational legal clinics. ${ }^{57}$ Further, she asserts that partnerships are more likely to

\footnotetext{
52 Beth Van Schaack, 'New California Human Rights Legislation' (Just Security, 6 October 2015). https ://www.justsecurity.org/26619/california-human-rights-legislation/. Accessed 25 June 2020.

53 Sarah Paoletti, 'Finding the Pearls When the World Is Your Oyster: Project Selection in Clinical Design' (2013) 5 Drexel Law Review 305, 355-356.

54 James J Silk, 'From Empire to Empathy? Clinical Collaborations between the Global North and the Global South-An Essay in Conversation with Daniel Bonilla' (2013) 16 Yale Human Rights and Development Law Journal 41.

55 Ibid. 46.

56 Sarah Paoletti, 'Preparing Lawyers for Practice in an Era of Global Urbanization: A Proposal for Transnational Clinical Partnerships' in Brian Spooner (ed), Globalization: The Crucial Phase (University of Pennsylvania Press 2015) 287.

57 Ibid. 295.
} 
be successful when both programmes expend similar levels of faculty and student resources, and have a shared understanding of what each partner will contribute. ${ }^{58}$ Finally, other authors have pointed out that the benefit of international collaboration is that it allows to us to turn the mirror onto ourselves- ' $[\mathrm{t}]$ eachers and students rediscover the culture, law, and legal system of their home countries when they "see it from the outside". 59 Transnational law imagines multiple different directional flows of law and information. With a wider toolkit of areas of law, a transnational law lens might encourage clinicians who teach clinics that work across borders to invite collaborations with law clinics in other countries and also to engage in clinical projects that shine the light back on human rights problems in the U.S.

Evidence of interest in and enthusiasm for global collaborations between law schools, especially those outside of the U.S., can be found in the existence and success of international organisations like the Global Alliance for Justice Education (GAJE). Starting as an informal group in the late 1990s, GAJE has become a key player in the global clinical movement. ${ }^{60}$ The GAJE alliance seeks to facilitate international information sharing and collaboration, and to support, develop, and implement advocacy projects on a global and regional basis. Furthermore, GAJE plays an administrative role in global justice education, holding conferences, workshops and trainings, and receiving and administering funds to support and innovate justice education in developing countries. ${ }^{61}$ To meet these goals, GAJE and its members regularly contribute to the conversation on global clinical education through GAJE's biannual global conferences, its regional initiatives, and communication network. ${ }^{62}$ As an 'immense and subtle' actor, GAJE has brought together a broad range of people with a common belief in justice education, and will continue to act as a catalyst for transnational collaboration. ${ }^{63} \mathrm{Next}$, I turn to a case study of a transnational clinical collaboration and explain how it aligns with a framework that is guided by transnational law.

\footnotetext{
${ }^{58}$ Ibid. 287.

${ }^{59}$ Kimberly D Ambrose, William HD Fernolz, Catherine F Klein, Dana Raigrodski, and Stephen A Rosenbaum, 'Cross-Border Teaching and Collaboration' in Deborah Maranville et al. (eds), Building on Best Practices: Transforming Legal Education in a Changing World (Lexis Nexis 2015) 148-151.

${ }^{60}$ Edward Santow and George Mukundi Wachira, 'The Global Alliance for Justice Education' in Frank S Bloch (ed), The Global Clinical Movement: Educating Lawyers for Social Justice (Oxford University Press 2010) 371.

${ }^{61}$ GAJE Alliance for Justice Education, GAJE Constitution. https://gaje.org/GAJE-Constitution. Accessed 27 July 2020. This constitution was adopted at GAJE's second worldwide conference in December 2001, held in Durban, South Africa.

62 Santow and Wachira, 'The Global Alliance for Justice Education' (n 60) 377-381.

${ }^{63}$ Ibid. 381.
} 


\section{Case study of a transnational law clinic: Collaboration between Cornell Law School, Ithaca and National Law University, Delhi}

In this section, we discuss our experience of collaborating with NLU, Delhi to address transnational surrogacy. In Section 5.1, we describe the structure and outcomes of the clinical collaboration. In 5.2, we briefly discuss the obstacles that accompany using a global classroom to facilitate transnational collaboration so that others may learn from our experience. Finally, Section 5.3 explains how our clinical collaboration fits within a framework of transnational law rather than international law.

\subsection{The structure of our clinic}

The collaboration between Cornell's International Human Rights Clinic and NLU, Delhi's Transnational Seminar in 2017 was a unique opportunity for students at Cornell Law School and NLU, Delhi to practise hands-on advocacy for human rights. Developed by Professors Aparna Chandra ${ }^{64}$ and Mrinal Satish ${ }^{65}$ of NLU, Delhi and Sital Kalantry ${ }^{66}$ of Cornell Law School, ${ }^{67}$ this project began with the mission of injecting the needs, voices, and rights of Indian surrogates into the discussion surrounding the Indian government's proposals to prohibit compensated surrogacy. ${ }^{68}$ Commercial surrogacy is a multi-million-dollar industry in India, ${ }^{69}$ and its prohibition created significant consequences for women's reproductive autonomy. To add another dimension to the conversation surrounding this policy shift, we aimed to

\footnotetext{
${ }^{64}$ For background on Dr Aparna Chandra, see her faculty biography here: https://nludelhi.ac.in/pep-facnew-pro.aspx? Id=45. Accessed 25 June 2020.

65 For background on Dr Mrinal Satish, see his faculty biography here: http://nludelhi.ac.in/pep-fac-newpro.aspx? $\mathrm{Id}=30$. Accessed 25 June 2020.

${ }^{66}$ For background on Professor Sital Kalantry, see her faculty biography here: https://www.lawschool. cornell.edu/faculty/bio_sital_kalantry.cfm. Accessed 25 June 2020.

67 Our clinic was also supported by two teaching fellows, Rebecca Helm and Keerthana Medrametla, and one teaching assistant, Samantha Elliott.

68 On 21 November 2016, the Government of India introduced the Surrogacy (Regulation) Bill in the Lok Sabha, or House of People, the lower house of India's bicameral Parliament. For the full text of the proposed bill and its progress, see the Surrogacy (Regulation) Bill (2016), PRS Legislative Service. https://www.prsindia.org/billtrack/surrogacy-regulation-bill-2016. Accessed 9 May 2020. This bill aimed to regulate the practice of surrogacy in India, with one key aspect being the complete prohibition of commercial surrogacy. Before legislative debate on the bill began, the government placed restrictions on commercial surrogacy. Nirmala George, 'Indian Surrogates Feel Hurt by Gov't Ban on Foreign Clients' (San Diego Union-Tribune, 17 November 2015). https://www.sandiegouniontribune.com/sdut-surrogates -feel-hurt-by-indias-ban-on-foreign-2015nov17-story.html. Accessed 20 June 2020. In particular, the Indian government prohibited commercial surrogacy for foreign intended parents, citing the need to protect India's poor from exploitation. See the Surrogacy (Regulation) Bill (2016) Chapter VII.

69 Sharmilla Rudrappa, 'India Outlawed Commercial Surrogacy-Clinics Are Finding Loopholes' (The Conversation, 23 October 2017). https://theconversation.com/india-outlawed-commercial-surrogacy-clini cs-are-finding-loopholes-81784. Accessed 20 June 2020. (estimating India's surrogacy industry garners between $\$ 400$ million and $\$ 1$ billion annually).
} 
create a human rights report describing the process of international and/or domestic surrogacy in India, the actors in this process, the current regulations, laws, and proposals, and, most importantly, the perspectives of surrogates. Using a comparative approach, we intended to draw on the best practices around the world in making our recommendations. We hoped our report could propose ways to regulate surrogacy in a manner that protected against exploitation, while also respecting women's reproductive autonomy.

This clinic seminar was taught through video conference to students both at NLU, Delhi and at Cornell Law School over the course of one semester. Students were assigned readings in a variety of different disciplines and areas of the law, affording substantive exposure to principles of CLE, international human rights law and its implementation, the domestic legal systems of both India and the U.S., and the realities of compensated surrogacy. ${ }^{70}$

Through simulation activities, students practised interviewing and investigated and explored strategies for promoting the protection of human rights. All 20 students contributed interview questions, brainstormed ideal interviewees, and prioritised topics and questions most important to the clinic's mission. ${ }^{71}$ Together, students also created a script for the beginning of each interview that explained the goals of the clinic and the context of the interview, and obtained the interviewee's consent.

In addition to the seminar component of the course, students were assigned research and writing assignments that would ultimately become the report this clinic aimed to create. ${ }^{72}$ Students from Cornell Law School and NLU, Delhi collaborated outside of class by dividing tasks, creating deadlines for drafts, and suggesting research questions and content. Certain class sessions were dedicated to giving students an opportunity to present, discuss, and receive feedback on their project work.

In April 2017, the Cornell students travelled to Delhi to engage with the NLU, Delhi students in person, assist with interviewing and fact-finding, and gain a better understanding of how surrogacy in India operates. Students interviewed surrogates, surrogacy agents, doctors, professors, and other stakeholders and policy makers over the course of this trip. Students conducted site visits in Delhi and Gujarat, taking notes to incorporate into the clinic's human rights report. One student, Jaeeun Shin, described the highlights of her trip: 'I'd say it's a tie between getting to travel all over India and interview the many actors involved in surrogacy and getting to participate in creating a policy report that may affect many, many people in the future. ${ }^{, 73}$

\footnotetext{
${ }^{70}$ Each week, students were also asked to respond to discussion questions and/or prepare a response to the week's reading. These assignments ranged from preparing a case brief to responding to hypothetical ethical scenarios.

71 Students designed questions for the following groups of interested parties: agents, doctors, feminist groups, government officials, intended parents, reproductive/surrogacy lawyers, and surrogates. In total, students wrote hundreds of interview questions pertaining to dozens of subject areas.

72 These sections were entitled: (1) comparative approaches to surrogacy; (2) international human rights and private law; (3) Indian laws, market, and policy; and (4) U.S. laws, market, and policy.

73 Cornell Law School, 'In "Global Classroom”, Students Study Surrogacy Law and Policy in India and the United States' (1 May 2017). https://www.lawschool.cornell.edu/spotlights/In-Global-ClassroomStudents-Study-Surrogacy-Law-and-Policy-in-India-and-the-United-States.cfm. Accessed 25 June 2020.
} 
Another student, Shannon Nakamoto, reflected on what she took away from this transnational clinical experience:

Being in India and speaking directly to those involved in the surrogacy process allowed me to understand how they viewed the ethical issues in light of their social and economic circumstances. After speaking with the surrogates (those most affected by our policy paper), I realized that the ethical issues (which my portion of the research deals with) are much more complex than I originally thought and that, when making any recommendations, I would need to remember to incorporate the views of the surrogates, rather than forcing my outsider's perspective on their future laws. ${ }^{74}$

At the end of the trip, students transcribed and shared their interview notes with the rest of the class. As a class, students identified common themes, contradictions, and new information to be added to the clinic's ultimate products. After returning home, students continued collaborating on our clinic's reports and worked to incorporate our fieldwork into each section.

Ultimately, our clinic produced two reports: one focused on India $^{75}$ and one focused on surrogacy in the U.S. ${ }^{76}$ These reports have been distributed widely, including to the Parliament Standing Committee on Health and Family Welfare in New Delhi, and the New York State Assembly. On 10 August 2017, a standing committee of the Indian Parliament heavily quoted from our report in rejecting the 2016 surrogacy bill which would have prohibited compensated surrogacy in India. ${ }^{77}$

Our clinic further created opportunities to participate in advocacy events outside the classroom. In March 2017, four students from our clinic shared their findings at a panel presentation held by the Commission on the Status of Women. The theme of that year's session was 'Women's Economic Empowerment in the Changing World of Work' and explored the ethical, legal, and medical implications of a surrogacy in India. As this panel took place before our class's trip to India, this event gave students the opportunity to present and defend their research, while also incorporating suggestions and critiques into the final product.

In March 2018, we shared our clinic's research with the greater Cornell community by hosting a panel entitled 'Comparative Perspectives on Surrogacy Law'. With Professor Kalantry acting as a moderator, one student from our clinic spoke about

\footnotetext{
74 Ibid.

75 Memorandum on the Surrogacy (Regulation) Bill, 2016 (13 April 2017). https://cpb-us-e1.wpmuc dn.com/blogs.cornell.edu/dist/2/7529/files/2017/08/CLPG-NLU-Delhi-Cornell-Memorandum-on-Surro gacy-Bill-2016-1s985d1.pdf. Accessed 25 June 2020. See also Cornell Law School, 'Indian Parliament Standing Committee Incorporate Views of Cornell International Human Rights Policy Advocacy Clinic'. https://kalantry.lawschool.cornell.edu/international-human-rights-policy-advocacy-clinic/past-projectsof-the-international-human-rights-clinic/indian-parliament-standing-committee-incorporates-views-ofcornell-international-human-rights-policy-advocacy-clinic/. Accessed 25 June 2020.

76 Cornell IHR Policy \& Advocacy Clinic and NLU, Delhi, Should Compensated Surrogacy Be Permitted or Prohibited: Policy Report Evaluating the New York Child-Parent Security Act of 2017 That Would Permit Enforceable and Compensated Surrogacy (September 2017). https://scholarship.law.cornell.edu/ cgi/viewcontent.cgi article=2685\&context=facpub. Accessed 25 June 2020.

77 See Cornell Law School, 'Indian Parliament Standing Committee' (n 75).
} 
our project, its findings, and the benefits of transnational clinical education. Professor Bruce Hale ${ }^{78}$ and Karen Rotabi ${ }^{79}$ also offered their expertise in the area, giving greater context and future implications for our work.

In May 2018, one former student and co-author of this essay, Rachael Hancock, testified in front of the New York State Assembly regarding the state's policy on compensated gestational carrier surrogacy and its Child-Parent Security Act. ${ }^{80}$ The New York State Assembly committee members asked her numerous questions in regard to the consequences of lifting the ban on surrogacy in New York Stateeventually lifted in $2020 .^{81}$

\subsection{Challenges of transnational collaborations}

While there are numerous benefits to the collaborations between academic institutions in the Global North and Global South, there are of course, also challenges. We describe our struggles, adaptations, and challenges in the hope that others who are interested in engaging in similar projects avoid some of these pitfalls.

Perhaps the biggest challenge for our clinic was our failure to focus on New York's surrogacy law at the outset of the project. Initially, the clinic set out with a goal of writing a report focused on Indian law and the Indian surrogacy industry. However, as our research progressed, we realised the irony (and perhaps hypocrisy) of a law school based in New York remaining silent about its home state's ban on compensated surrogacy. ${ }^{82}$ Reallocating resources, time, and energy to accommodate a new report comparing New York's practices to the rest of the U.S. required students and teachers within our clinic to adapt and reorganise midway through the semester. Tailoring this report to a separate audience, including new data, and developing a research plan after the start of the clinic proved to be an unforeseen, but necessary, challenge. Ultimately, this second report was a useful tool for our clinic and presented opportunities for Cornell students to act locally as well as globally, as suggested by Carrillo and Yaksic. ${ }^{83}$

Another challenge we faced was communication. Through technological advances, almost all of our seminars throughout the semester were held via audiovisual teleconference, enabling us to see and hear each other between New Delhi

\footnotetext{
${ }^{78}$ For background on Professor Bruce Hale, see his biography here: https://www.modern-family-law. com/about.html. Accessed 25 June 2020.

79 For background on Professor Karen Rotabi, see her biography here: https://csumb.edu/directory/perso n/krotabi. Accessed 25 June 2020.

80 To watch video of this testimony, see 5-24-18 Public Hearing on Gestational Surrogacy. http://nysta teassembly.granicus.com/MediaPlayer.php?view_id=8\&clip_id=4709. Accessed 9 May 2020.

81 Cornell Law School, 'Rachael Hancock'18 Testifies before New York State Assembly on Surrogacy Bill' (11 June 2018). https://www.lawschool.cornell.edu/spotlights/Rachael_Hancock_Testifies_NYS_ Assembly.cfm. Accessed 25 June 2020.

82 New York is one of two states in the U.S. that bans compensated surrogacy. The other state is Michigan. See generally, Cornell IHR Policy \& Advocacy Clinic and NLU, Delhi, Should Compensated Surrogacy Be Permitted (n 76).

83 See Carrillo and Yaksic, 'Re-imagining the Human Rights Law Clinic' (n 23) 105.
} 
and Ithaca. Though this technology undoubtedly improved our transnational clinic, it was far from perfect. As anyone who has made use of a video conferencing service knows, a free-flowing conversation among 20 people is difficult to facilitate. Learning each other's names, personality, opinions, and working styles remained difficult—often our separate classrooms in Ithaca and New Delhi would speak at each other and wait for a response, rather than holding a joint conversation. We trust that as technology advances and people become more comfortable with distance learning in light of the global pandemic, this issue will become less and less salient in the global classroom. ${ }^{84}$

We also encountered a number of small, logistical issues over the course of this clinical programme. For instance, NLU, Delhi and Cornell Law School unsurprisingly do not follow the same academic schedule. For Cornell students, the first class of the semester occurred before NLU, Delhi was in session for the winter 2017 term. For NLU Delhi students, the beginning of our week-long fact-finding and interview period coincided with the tail end of exams. As expected, extracurricular activities and external events between the two schools were not coordinated. In anticipation of these situations during which some students would not be able to contribute equally, we included a section discussing teamwork and responsibilities in the syllabus, and asked students to discuss any foreseeable time conflicts at the outset of the semester. By and large, students were able to work together to overcome these scheduling issues, but it was important to be cognisant of time constraints throughout the semester.

The time change between New Delhi and Ithaca was easily foreseen, but not so easily surmounted as a factor in our clinic's classroom dynamic. Our seminars were held on Thursday mornings in New York, and Thursday evenings in New Delhi. This had the unfortunate impact of cutting through the time the NLU, Delhi students would normally eat dinner in their residential law school. While it was not ideal for them, dinner was provided for those students during the clinic seminar. It is difficult to quantify how time differences contributed to communications trouble between group members and our class generally, but nonetheless important to take into consideration the convenience of a global classroom. Fortunately, we took into account daylight savings time, which requires the NLU, Delhi students to change their schedule by one hour. While we would have preferred to have changed the schedule of the Cornell students, that proved to be more difficult due to the lack of classrooms and overlapping classes during the morning time at Cornell; it was easier to schedule the seminars during the evening time at NLU, Delhi since there were not many other conflicting classes for students.

\footnotetext{
${ }^{84}$ Even before the COVID-19 outbreak of 2020, demand for collaboration software and video conferencing technology was on the rise. As business communication apps continue to see record levels of use, the scramble to improve video conferencing technology has begun. See Charlotte Trueman, 'Pandemic Leads to Surge in Video Conferencing App Downloads' (ComputerWorld, 3 April 2020). https://www. computerworld.com/article/3535800/pandemic-leads-to-surge-in-video-conferencing-app-downloads. html. Accessed 25 June 2020. See also Heather Kelly, 'The Most Maddening Part about Working from Home: Video Conferences' (Washington Post, 6 March 2020). https://www.washingtonpost.com/techn ology/2020/03/16/remote-work-video-conference-coronavirus/. Accessed 25 June 2020.
} 
With 20 students contributing to this report, editing, uniformity, and coherence were destined to be a challenge. However, with student authors from two legal education systems, this task was even greater. Deciding on a uniform citation method and spelling were two tasks we attempted to address at the outset of our writing, but differences in vocabulary, writing style, and writing conventions were more complex, nuanced issues to address. In practice, we found it took a significant effort to compile and edit our four teams' sections in finished products. Practitioners in a transnational legal clinic should be aware that the global classroom may require more time to compile, edit, and adapt reports written by students from different academic systems and cultures.

\subsection{Benefits of using transnational law as a framework}

This clinical collaboration was guided by a transnational framework rather than solely an international human rights approach. As described above, we have identified three potential benefits of using transnational law (rather than just international law) to guide clinics who work across borders to promote social justice. First, a transnational law framework allowed us to focus on the many important aspects of transnational surrogacy by using many areas and levels of substantive laws (using private and domestic law, in addition to international human rights law). Second, transnational law allowed us to hold both public and private actors involved in surrogacy transactions accountable by pointing out their obligations and duties under various areas of law. Third, a collaboration with a law school in India was crucial for us in furthering this project in order to include a nuanced and in-depth analysis of the Indian surrogacy law.

\subsection{Using multiple areas of substantive law}

Surrogacy involves multiple areas of law, especially in cases where parents are from one country and a surrogate is from another. Even when intended parents and surrogates reside in the same country, multiple areas of laws are implicated, including nationality law, contract law, fertility law, and family law. As a result, students participating in the global clinic were asked to discuss, interpret, and apply domestic, international, and foreign law through the course of report writing and field research. Had we focused on only international human rights law, we would have missed many important ways in which many surrogates are unfairly treated.

For our Indian-centred report, we included Indian domestic law, arguing why a complete ban was inconsistent with India's constitution and local laws. For our New York-centred report, we turned to state law to argue that New York's laws were inconsistent with its state constitution and its family laws. Both reports relied heavily on comparative law to emphasise that a complete ban on surrogacy is not only an outmoded means of regulation, but also increasingly out of step with countries across the world. The New York report also compared state law across the U.S. to highlight that only two of fifty states completely ban surrogacy. We also discussed the extraterritorial application of domestic laws, such as France's ban on surrogacy 
contracts performed wholly in the U.S., to speak to the implementation and realities of a complete ban.

By broadening our scope beyond international human rights law, we were able to ensure that our reports discussed the consequences of a ban on compensated surrogacy from a number of different angles. Including multiple areas of law in our report not only challenged students to tackle new substantive laws, but also allowed us to address a wider audience outside of the international human rights community.

\subsection{Addressing public and private actors}

When focusing on issues of surrogacy, it was critically important to examine the role of both private and public actors in perpetuating inequality. While the state ultimately regulates the compensated surrogacy industry, often the treatment and compensation of surrogates, expectations of intending parents, and the lives of children born through surrogacy are driven by private actors. The role of non-state actors is magnified in cases of transnational surrogacy agreements where brokers, agencies, and caretakers play an even bigger role in the communication, negotiation, and performance of compensated surrogacy contracts.

As part of our fieldwork, we interviewed doctors who run surrogacy clinics, agents who identify and communicate with surrogates, and surrogates themselves in both India and the U.S. Had we confined our fieldwork to elected officials who would ultimately write surrogacy legislation, our report would not have benefited from the rich detail talking with private actors provided us. More importantly, focusing solely on the responsibility of public actors would not have allowed us to identify and critique the ways in which the private contract process between the surrogates and the intended parents as mediated by the surrogacy clinics is unfair to surrogates both procedurally and substantively.

\subsection{Transnational collaboration between academic institutions}

Working on issues involving the domestic law of multiple jurisdictions and its extraterritorial application necessitates working with clinics or organisations in other countries that are more familiar with those domestic laws. By working with students in different countries, students also benefited by engaging in peer-to-peer learning and enjoyed the opportunity to hear, share, and respond to different cultural and legal perspectives. As part of this collaboration, students learned to self-critique the legal tradition they were brought up in and check assumptions about good governance and access to justice, as well as the role of government, the meaning of equality, and the role of international human rights. Students were pushed to learn foreign law in context and apply their newfound skills as advocates.

To write our report, we formed small teams of students from both NLU, Delhi and Cornell. Students relied on each other to lend context to elements of the foreign legal system that was the subject of their report. Though these projects were guided through readings and class discussion, the bulk of this learning was done through student conversation, peer editing, and group presentations. 
While American students explained the context of In re Baby $M$ to Indian students one week, ${ }^{85}$ Indian students were tasked with explaining the process the Surrogacy (Regulation) Bill would face during legislative debate. Less formally, students shared information and opinions on ethical issues, ideologies, and feminist jurisprudence as they wrote their respective reports.

In order to write a coherent report, reaching a consensus was a vital goal of our clinic. In reaching this consensus, our clinic engaged in a number of lively debates about human rights generally, and surrogacy more specifically. Students' trust in good governance, pessimism about black markets, and reactions to human rights as a construct varied significantly among clinic members based on the country where they were based, sparking constructive, nuanced, and at times heated conversation. By the same token, these cross-border, cross-cultural conversations also inspired our students to critique their own world view and assumptions regarding capitalism, labour, and the role of government.

\section{Conclusion}

CLE has evolved significantly since it was conceived in the 1930 s to become a more formal part of law schools. In the 1980s, a new wave of clinical programmes started across U.S. law schools known as 'international human rights clinic' with the goal of holding state governments accountable for human rights violations. In this article, we suggested that clinics that address global inequalities and issues should adopt a wider lens. The body of literature known as 'transnational law' offers such a framework.

First, to address global inequality, violence, and other problems, we need tools beyond international human rights law. A transnational law framework allows us to include other areas of substantive law at both the domestic and the international level. Second, transnational law allows us to examine the work of both state and non-state actors and identify where they are contributing to global injustice. Indeed, today non-state actors such as corporations wield significant global power and their operations can have significant negative harm on vulnerable communities around the world. Third, in addressing problems that involve actors and people interacting across multiple countries, it is helpful for clinics to engage in collaborations with other law clinics around the world that have expertise in domestic law as well as other areas of law.

This article argues for broadening the traditional methodology of international human rights clinics. Typically, IHR clinic projects involved holding only state actors accountable using international human rights law. Since the first IHR clinic

\footnotetext{
85 In re Baby M, 109 N.J. 396 (1988) was a custody case concerning the legal parentage of a child born through traditional surrogacy. This case became the first American court ruling on the validity of surrogacy contracts in the U.S. and attracted significant attention regarding the legal and social questions of parenthood and surrogacy. This case continues to be precedent in New Jersey and has been extended to apply to gestational surrogacy as well as traditional surrogacy. See A.G.R. v. D.R.H., 2009 N.J. Super. Unpub. LEXIS 3250 (23 December 2009).
} 
was founded in 1979, the world has changed significantly. Private actors have gained power and contribute significantly to global injustice and people and organisations are increasingly crossing borders and their actions implicate multiple areas of law. A transnational law framework (rather than one that focuses only on international law) gives clinics that are working to promote global justice a broader and more rigorous toolkit.

Acknowledgements I am honoured to be participating in a symposium to honour Professor NR Madhava Menon. Professor NR Madhava Menon will always be remembered for his immense contributions to modern legal education in India. His commitment to legal education will not soon be forgotten, and it is our duty to continue to innovate, improve, and invigorate legal education in his memory.-Sital Kalantry. Thank you to Cornell Law School for the meaningful opportunity to engage in clinical legal education during my time as a law student.-Rachael Hancock

Publisher's Note Springer Nature remains neutral with regard to jurisdictional claims in published maps and institutional affiliations.

\section{Authors and Affiliations}

\section{Sital Kalantry ${ }^{1} \cdot$ Rachael Hancock ${ }^{2}$}

Sital Kalantry

skalantry@cornell.edu

Rachael Hancock

reh284@cornell.edu

1 Cornell Law School, Ithaca, USA

2 United States District Court for the District of New Jersey, Camden, USA 